\title{
Geological dimension of the cultural heritage: A case example of the Ajanta Caves (Maharashtra, India)
}

GONTAREVA, E.F. ${ }^{1}$, ANSARI, M.K. ${ }^{2}$, RUBAN, D.A. ${ }^{3,4,5^{*}}$, AHMAD, M. ${ }^{2} \&$ SINGH, T.N. ${ }^{2}$

(1) Tourism Program, Higher School of Business, Southern Federal University, 23-ja linija Street 43, Rostov-na-Donu, 344019, Russia

(2) Department of Earth Sciences, Indian Institute of Technology Bombay, Powai, Mumbai, 400076, India

(3) Department of Tourism, Higher School of Business, Southern Federal University, 23-ja linija Street

43, Rostov-na-Donu, 344019, Russia

(4) International Agency for Minerals Policy ('MinPol'), Austria

(5) contact address: P.O. Box 7333, Rostov-na-Donu, 344056, Russia; ruban-d@mail.ru

* corresponding author

https://doi.org/10.17979/cadlaxe.2015.38.0.3683

\begin{abstract}
International development for the both geoconservation and geotourism requires attention to all kinds of (potential) geological heritage. The Ajanta Caves (western Maharashtra, India) is a famous cultural object consisting of 30 caves carved in the Deccan Traps and inscribed to the UNESCO list of the World Heritage Sites. Its examination permits to indicate four geological features, which are the artificial caves themselves (these mark geological activity of the man in the historical past), the end-Cretaceous flood basalts (these demonstrate the emplacement of Large Igneous Province and the relevant palaeoenvironmental catastrophe), the gorge of the Waghora River (this is peculiar landform resulted from the river erosion of hard rocks), and the rockfall hazard (this is an interesting engineering geological phenomenon linked to the caves construction/maintenance). Geological heritage value of these features is argued. Unfortunately, there is not any geotourism activity at the Ajanta Caves presently. The content analysis of the principal on-line resources (web pages) devoted to this cultural site reveals the absence of sufficient geological information that would
\end{abstract}


facilitate geotourism. Generally, judgements about the Ajanta Caves and the other similar sites in the geological dimension permit to consider the wide spectrum of the geological heritage. They also highlight some extra opportunities for geotourism, which can benefit by its development at cultural sites with thousands of visitors.

Key words: Ajanta Caves; Deccan basalts; Geological heritage; Geotourism; World Heritage Site. 


\section{INTRODUCTION}

Geological heritage is a wide category, and it embraces exceptional geological objects in-situ (so-called "geosites") and ex-situ (specimens in museum collections) (Wimbledon \& Smith-Meyer, 2012; Gray, 2013; Prosser, 2013; Ruban, 2013). However, it would be wrong to limit the geological heritage to the only geological objects sensu stricto. In fact, this category includes also cultural items with heritage value that is (or may be) partly determined by their geological importance (cf. Hose, 2000; Migon, 2009; Necheş \& Erdeli, 2014). Moreover, the geological experience is tied closely to the cultural experience (Tang, 2000; Goudie, 2002; Panizza \& Piacente,
2009; Gordon, 2012; Gray, 2013; Lubova et al., 2013; Necheş \& Erdeli, 2014). By example of Petra (Jordan), Migon (2009) demonstrated that the well-known UNESCO World Heritage Sites of cultural importance may also have geological heritage value.

In this article, we draw attention to the geological dimension of the world-famous cultural heritage object, namely the Ajanta Caves (Maharashtra, India). Similar to the above-mentioned Petra, it is also inscribed to the UNESCO list of the World Heritage Sites. Our aim is to recognize the main geological features of this site, to determine their geological heritage value, and to consider the importance of this value for the local tourism development.

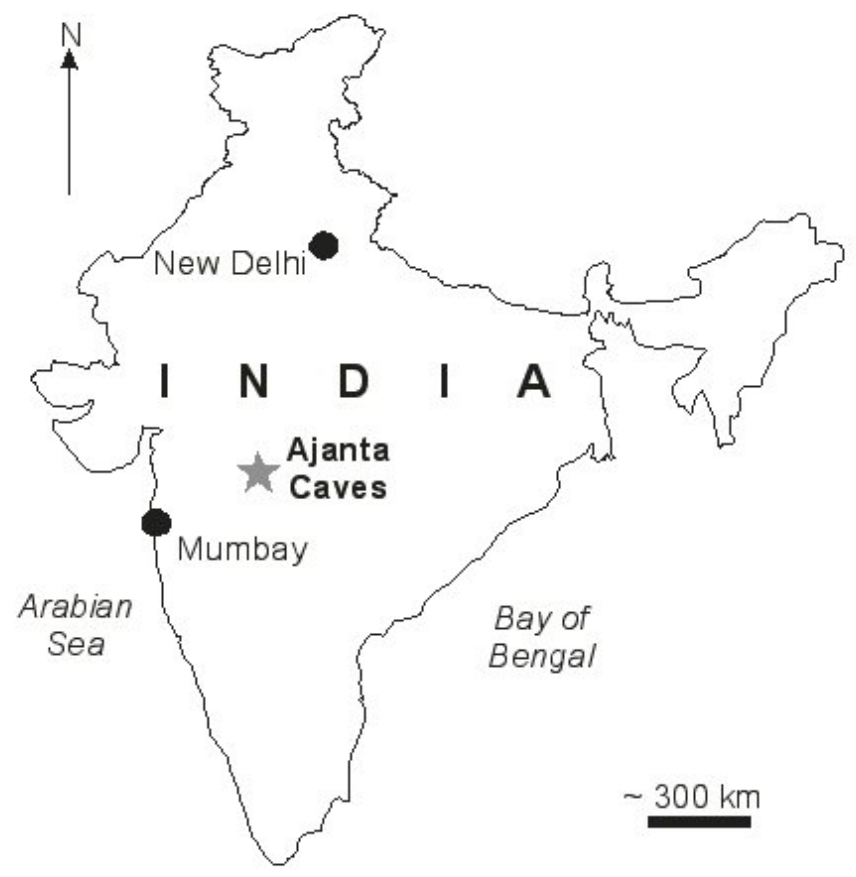

Fig. 1. Geographical location of the Ajanta Caves. 


\section{THE AJANTA CAVES WORLD HERITAGESITE ANDITS GEOLOGICAL SETTING}

The Ajanta Caves are located in the western part of the Maharashtra State of India (Fig.1). These are 30 artificial caves in the cliff above the valley (gorge) of the meandering Waghora River (Fig. 2). They were excavated (particularly, for the Buddhist ritual purposes) in two phases during the period of the 2 nd century B.C. -6 th century A.D.; later, they were abandoned and re-discovered in 1819. In 1983, they were inscribed to the UNESCO list of the World Heritage Sites (see relevant documents at http://whc.unesco.org/en/ list/242). The cultural heritage value of the Ajanta Caves is determined by the cave architecture, wall paintings, and sculptures. Undoubtedly, the huge size of the caves also matters; at least, the Ajanta Caves is among the largest historical sites in the UNESCO list.

The geological setting of the Ajanta Caves was characterized recently by Ansari et al. (2014). The Ajanta Caves are carved in a compound basalt flow of the Ajanta Formation belonging to the Sahyadri Group of the Deccan Traps. Researches have identified five basaltic flows of alternating "aa" and compound "pahoehoe" characters (Walker, 1971; Bondre et al., 2000, 2004). The thickness of individuals flows ranges from a very few to $80 \mathrm{~m}$ (GSI, 2001). The compound "pahoehoe" flows show ropy structure and vesicular top with spheroidal vesicles, whereas the "aa" flows are dark grey and massive with fragmentary top and base (Rana \& Vishwakarma, 1990).

\section{METHODS}

This study employs two qualitative approaches. The first approach is general evaluation of the geological heritage. At the beginning, we recognize the geological features that are linked to the Ajanta Caves World Heritage Site. For this purpose, the geological setting of this cultural heritage site is analyzed. The features are classified according to the typology of geological heritage proposed by Ruban (2010) and Ruban \& Kuo (2010). Then, it is attempted to determine the geological heritage value of these features. This is possible via consideration of the degree of uniqueness of the latter, i.e., the rarity of the features on international, national, regional, or local scales. This degree also depends on the importance of the geological features for science, education, and tourism. We also attempt to follow the principle of interpretation of cultural objects in the terms of geology that was offered by Migon (2009).

Recognition of any geological heritage value of the cultural object indicates its geotourism potential. As suggested by our examination of the site and queries to the local authorities, there are not geotourism activities linked to the Ajanta Caves presently. However, visitors of such important sites may decide to pay attention to geology themselves through the available on-line resources (supposedly demanded by many tourists), if the relevant information is presented there. Therefore, our second approach is the content analysis of the on-line resources devoted to the Ajanta Caves. Direct or indirect consideration of geological phenomena on several principal web pages is checked in order to conclude about the availability of on-line geotourist resources and their quality. 


\section{GEOLOGICAL FEATURES AND THEIR HERITAGE VALUE}

The most striking geological feature to be recognized at the Ajanta Caves World Heritage Site is the caves themselves. The excavation of 30 caves with the maximum length of $>35 \mathrm{~m}$ (see physical parameters in the catalogue of the caves provided by the Archaeological Survey of India at http:// asi.nic.in/asi_monu_whs_ajanta.asp) in hard basalts reflects voluminous geological/geomorphological activity of the man in the historical past (Fig. 2). According to the classification of Ruban (2010) and Ruban \& Kuo (2010), the caves can be judged geohistorical feature. Its international geological heritage value is evident because of the above-mentioned huge size of the en- tire cave ensemble. The attempted extraction of basalts linked to excavation of the Ajanta Caves was really huge, and this fact confirms the idea of humans as geologicalscale agents (Hooke, 2000; Wilkinson, 2005; Goudie, 2013). Moreover, the cave excavation is a very peculiar example of the geological/geomorphological activity of the man, because it differs from the types of this activity (mining, quarrying, etc.) that are commonly mentioned in discussions of the anthropogenic influences on the geological environment (e.g., Goudie, 2013). Evidently, the Ajanta Caves can be used efficiently by geologists/geomorphologists for the purposes of demonstration of how strongly past civilizations could alter the geological environment and what were their abilities of construction of new landforms.

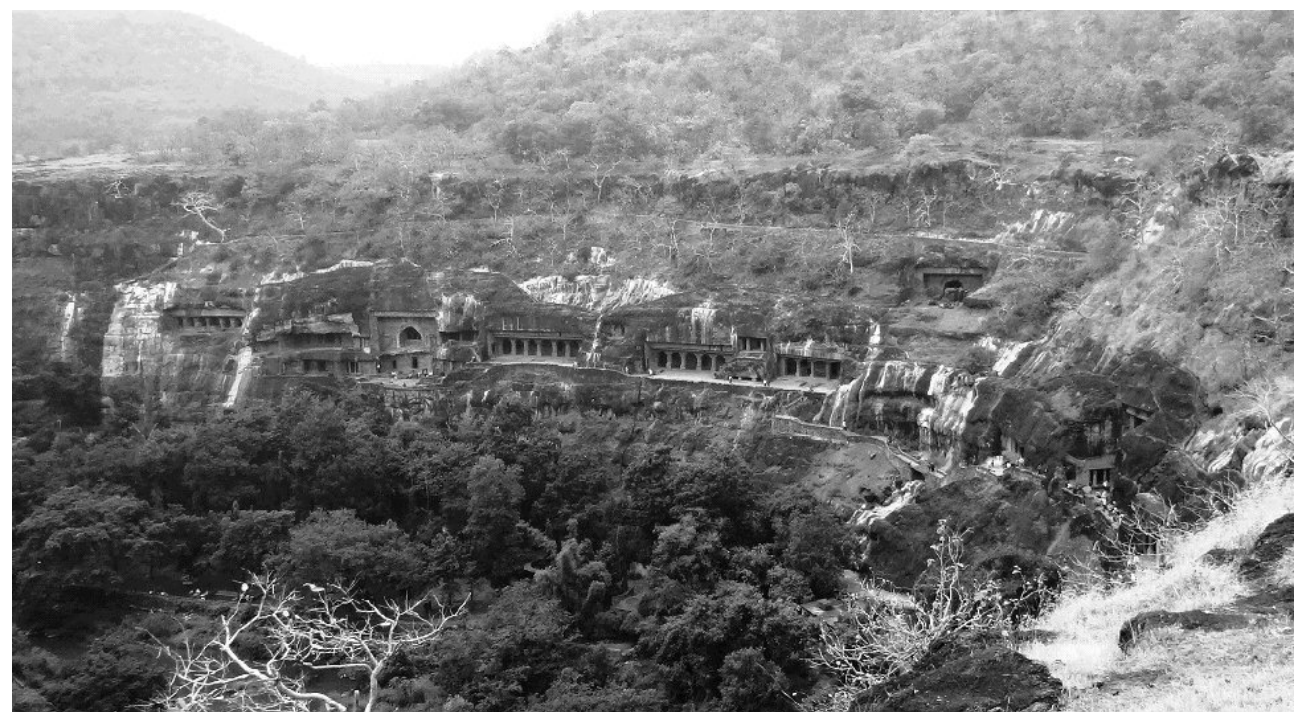

Fig. 2. Panoramic view of the Ajanta Caves World Heritage Site.

The other important geological feature is the rocks, in which the Ajanta Caves were excavated. These are the flood basalts (traps) of the Deccan Plateau (Ansari et al., 2014) that were emplaced at the Cretaceous-Paleogene transition (Courtillot \& Renne, 2003; 
Baksi, 2014). These basalts are of outstanding interest because of two reasons. Firstly, they are typical products of the mantle plume activity resulted in the appearance of a large igneous province (LIP) of huge size in the end of the Mesozoic Era (Wignall, 2001; Abbott \& Isley, 2002; Courtillot \& Renne, 2003; Jerram \& Widdowson, 2005; Courtillot, 2007; Baksi, 2014). Secondly, the emplacement of this LIP is considered among the main possible triggers of the endCretaceous global environmental crisis and the relevant mass extinction that devastated both continental and marine ecosystems and marked the end of ammonites and dinosaurs (Hallam \& Wignall, 1997; Keller, 2003; Courtillot, 2007; Keller et al., 2008) (see Alvarez (2008) and Vajda \& Bercovici (2014) for alternative explanation of this catastrophe). Undoubtedly, there are many geological localities in India with the exposures of the Deccan traps. However, the ex- cellent accessibility and the appropriate conservation of the Ajanta Caves, as well as the good visibility of outcropped basalts make this site ideal for explanation of the Deccan flood basalt volcanism and the relevant palaeoenvironmental perturbations. This consideration permits to conclude about the regional-to-national geological heritage value of the igneous rocks from the Ajanta Caves World Heritage Site.

Of interest is the deep gorge of the meandering Waghora River, which is a peculiar geomorphological feature. On the one hand, it permits to see deep river erosion of hard rocks (basalts). On the other hand, the gorge has a spectacular horseshoe shape (Fig. 3). Additionally, cave excavation changed the natural landform and added artificial elements to it, and these changes are really impressive (see also above). These seem to be enough to judge about the Ajanta Caves as a local geomorphosite.

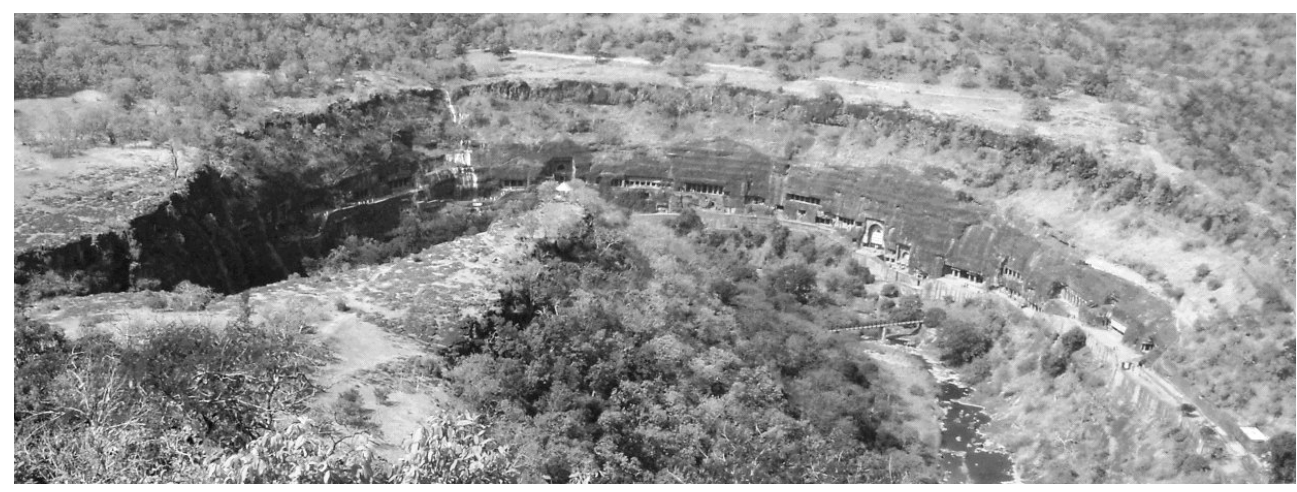

Fig. 3. The gorge of the meandering Waghora River - a peculiar landform.

Finally, rockfall hazard in the Ajanta Caves was explored recently by Ansari et al. (2014). As this phenomenon was proven possible, the engineering geological feature (according to the classification of Ruban (2010) and Ruban \& Kuo (2010)) should be recognized. It is of international heritage value because of two reasons. Firstly, although rockfalls are common slope processes (Guzzetti, 2013), their occurrence linked to caves is of special interest. On the other hand, rockfalls and other engineering 
geological processes at important cultural sites should be treated as something specific because of their possible links to rock massif weakness resulted from the construction/maintenance of these sites and also because of significant possible damage or total lost of unique cultural objects. Thus, the investigations of Ansari et al. (2014) have made the Ajanta Cave an ideal site for such rockfall studies. Slope processes are also of interest because of the implemented mitigation strategy, which is specific at the World Heritage Sites (at least, slope protection structures should be efficient, but they should not distract attention of visitors from the site itself - see Fig. 4).

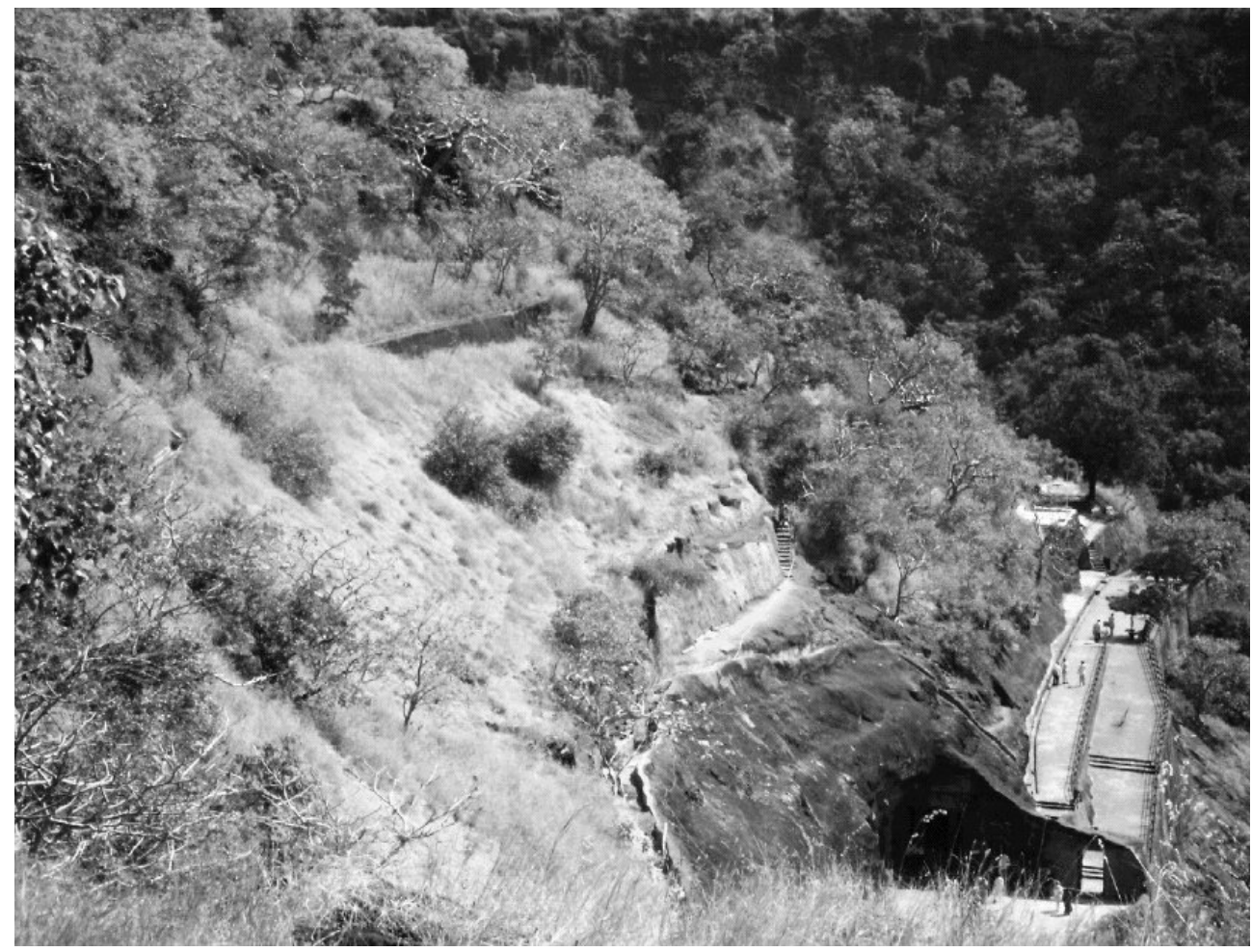

Fig. 4. Structure erected for slope protection at the Ajanta Caves World Heritage Site. It is designed "ideally" to avoid distraction of visitors' attention from the site itself, this structure looks similarly to authentic natural (basalts) and artificial (caves) features.

\section{ON-LINE GEOTOURIST RESOURCES}

The presence of four geological features (geohistorical, igneous, geomorphological, and engineering geological) at the Ajanta Caves that are all of heritage value highlight the big geotourism potential of this World Heritage Site. Although geotourism activity is lacking there, on-line resources would permit visitors to learn about the geological importance of this site in addition to its outstanding cultural essence. Five main 
web resources that can serve as the main sources of the knowledge about the Ajanta Caves for tourists are provided by the UNESCO (http://whc.unesco.org/en/list/242), the Archaeological Survey of India (http:// asi.nic.in/asi_monu_whs_ajanta.asp), the Maharashtra Tourism Development Corporation Ltd. (http://www.maharashtratourism.gov.in/mtdc/HTML/MaharashtraTourism/TouristDelight/Caves/Caves. aspx?strpage $=$ AjantaCaves.html), the Sacred Destinations (http://www.sacred-destinations.com/india/ajanta-caves), and the SANTRONIX Group (http://ajantacaves. $\mathrm{com} /)$. All are very informative with regard to the location of the site, its history, cultural heritage, conservation activities, and tourism opportunities. Unfortunately, none of them pay direct attention to geological features that one can observe together with the cultural heritage objects.

Indirect indications on geological features are available in the noted web resources, but they are too few and 'dispersed' among the other information. For instance, the UNESCO web page (http://whc.unesco.org/en/ list/242) allows downloads of some official documents, where the local geology is explained briefly. Although it is unlikely that potential visitors will read these documents with attention, "volcanic lava" (a bit awful term) of the Deccan Plateau is also mentioned on the web page itself. The gorge of the Waghora River as a peculiar landform is considered in several web resources (e.g., see http://ajantacaves.com/). And, of course, physical parameters of the caves and the methods of their excavation (these permit to envisage the geological/geomorphological activity of the past civilizations) are mentioned here and there. Some geologically-wrong information is also found. The web page of the
SANTRONIX Group (http://ajantacaves. com/) informs about granite layers, although these are basalt layers in fact (GSI, 2001). Generally, what has been found on the noted web pages is not enough to judge these pages sufficient geotourist resources.

\section{DISCUSSION}

Why judgements of the cultural heritage in the geological dimension are necessary? In our opinion, they permit to extend the understanding of the geological heritage. The example of the Ajanta Caves demonstrates that some geological phenomena with heritage value can be found in 'purely' artificial objects. If so, is it not a new form of the geological heritage?! It seems to be sensible to note that Panizza \& Piacente (2009) went so far to conclude about the importance of cultural aspects to the wide definition of geodiversity.

Determination of the geological features in the Ajanta Cave provides extra opportunities with regard to tourism. The annual number of visitors of this well-accessible site is very large and reaches hundreds of thousands per year (see statistics at http:// whc.unesco.org/en/list/242). Their interest and satisfaction can be increased via 'diversification' of excursions by merging cultural and geological experience. And, vice versa, geotourism can also benefit from the latter. This activity grows rapidly, but still needs significant progress on the international scale (Hose, 2000; Dowling \& Newsome, 2010; Hose \& Vasiljevi冈, 2012). If visits to the World Heritage Sites is so important driver of the global tourism (Yang et al., 2010; Poria et al., 2013; Su \& Lin, 2014), explanation of geological peculiarities at such sites may help to promote geotourism. 
Migon (2009) also considered the opportunity of enhancing geotourism via its development at such cultural heritage sites as Petra in Jordan. Geotourism development can be achieved by the local authorities and the international community of specialists in geoconservation and geotourism. The situation with the geological information on the Ajanta Caves World Heritage Site available on-line (see above) indicates how much should be done yet to promote geotourism at this site. However, presentation of sufficient geological knowledge on the already-available web pages will be an easy task. This would permit to faciliate geotourism development at the studied site because of the high importance of on-line resources for tourists. Excursion guides training (e.g. rise of their awareness of the geological heritage linked to the Ajanta Caves) seems to be also helpful. The noted tasks can be achieved via the activity of local, national, and/or international geoconservation/geotourism organizations.

Two additional remarks on tourism activities in the Ajanta Caves are necessary. Firstly, full consideration of the geological context of this site may enhance understanding of the visitors' emotion and satisfaction. We hypothesize that artificial caves may be so attractive also by analogy with natural caves. The picturesque gorge of the Waghora River, where the studied site is located, also increases potentially the attractiveness of the site. Secondly, the detailed investigation of the geological phenomena linked to the Ajanta Caves attempted by Ansari et al. (2014) permitted to judge about the tourist safety issues.

\section{CONCLUSION}

The case example of the Ajanta Caves in India demonstrates that cultural herit- age objects may have recognizable geological features, some of which are of geological heritage value. Coupled with the earliermade similar conclusion on the other worldfamous cultural heritage site, namely Petra in Jordan (Migon, 2009), the significance of the cultural objects for the purposes of geoconservation and geotourism appears evident. Some efforts for further promotion of the Ajanta Caves as a geotourist destination are necessary, because the geological information about this UNESCO World Heritage Site (at least, presented by the principal on-line resources) is insufficient.

The attempted study stresses the general importance of judgements about the cultural heritage in the geological dimension. If so, it seems to be both urgent and interesting to analyze the geoconservation and geotourism potential of the other cultural sites of the world.

\section{ACKNOWLEDGEMENTS}

The authors gratefully thank J.R. Vidal Romaní (Spain) for his editorial support, as well as T.A. Hose (UK), I.-M. Necheş (Romania), W. Riegraf (Germany), and the other colleagues for their help with literature.

\section{REFERENCES}

Abbott, D.H. \& Isley, A.E. (2002). The intensity, occurrence, and duration of superplume events and eras over geological time. Journal of Geodynamics, 34: 265-307.

Alvarez, W. (2008). T. rex and the Crater of Doom. Princeton University Press, Princeton, $185 \mathrm{pp}$.

Ansari, M.K., Ahmad, M., Singh, R. \& Singh, T.N. (2014). Rockfall hazard as- 
sessment at Ajanta Cave, Aurangabad, Maharashtra, India. Arabian Journal of Geosciences, 7: 1773-1780.

Baksi, A.K. (2014). The Deccan Trap - Cretaceous-Paleogene boundary connection; new 40Ar/39Ar ages and critical assessment of existing argon data pertinent to this hypothesis. Journal of Asian Earth Sciences, 84: 9-23.

Bondre, N.R., Duraiswami, R.A., Dole, G., Phadnis, V.M. \& Kale, V.S. (2000). Inflated Pahoehoe lavas from the Sangamner area of the western Deccan volcanic province. Current Science, 78: 1004-1007.

Bondre, N.R., Duraiswami, R.A. \& Dole, G. (2004). Morphology and emplacement of flows from the Deccan volcanic province, India. Bulletin of Volcanology, 66: 29-45.

Courtillot, V. (2007). Evolutionary catastrophes - the science of mass extinction. Cambridge University Press, Cambridge, $173 \mathrm{pp}$.

Courtillot, V.E. \& Renne, P.R. (2003). On the ages of flood basalt events. Comptes Rendus Geosciences, 335: 113-140.

Dowling, R. \& Newsome, D. (2010). Geotourism: a Global Activity. In: Dowling, R. \& Newsome, D. (Eds.). Global geotourism perspectives. Goodfellow Publishers, Woodeaton, pp. 1-17.

Gordon, J.E. (2012). Rediscovering a Sense of Wonder: Geoheritage, Geotourism and Cultural Landscape Experiences. Geoheritage, 4: 65-77.

Goudie, A. (2002). Aesthetics and relevance in geomorphological outreach. Geomorphology, 47: 245-249.

Goudie, A. (2013). The Human Impact on the Natural Environment: Past, Present and Future. Wiley-Blackwell, Chichester, $410 \mathrm{pp}$.
Gray, M. (2013). Geodiversity: Valuing and conserving abiotic nature. Wiley-Blackwell, Chichester, 495 pp.

GSI, 2001. Geoscientific studies for the conservation of Ajanta Caves. Report Submitted by the Central region of GSI, Nagpur.

Guzzetti, F. (2013). Rockfall. In: Bobrowsky, P.T. (Ed.). Encyclopedia of Natural Hazards. Springer, Dordrecht, pp. 875-877.

Hallam, A. \& Wignall, P.B. (1997). Mass extinctions and their aftermath. Oxford University Press, Oxford, 320 pp.

Hooke, R.LeB. (2000). On the history of humans as geomorphic agents. Geology, 28: 843-846.

Hose, T.A. (2000). European 'geotourism' - geological interpretation and conservation promotion for tourists. In: Barettino, D., Wimbledon, W.A.P., Gallego, E. (Eds.). Geological heritage: its conservation and management. ITGE, Madrid, pp. 127-146.

Hose, T.A. \& Vasiljević, D.A. (2012). Definig the nature and purpose of modern geotourism with particular reference to the United Kingdom and south-east Europe. Geoheritage, 4: 25-43.

Jerram, D.A. \& Widdowson, M. (2005). The anatomy of Continental Flood Basalt Provinces: geological constraints on the processes and products of flood volcanism. Lithos, 79: 385-405.

Keller, G. (2003). Biotic effects of impacts and volcanism. Earth and Planetary Science Letters, 215: 249-264.

Keller, G., Adatte, T., Gardin, S., Bartolini, A. \& Bajpai, S. (2008). Main Deccan volcanism phase ends near the K-T boundary: Evidence from the KrishnaGodavari Basin, SE India. Earth and Planetary Science Letters, 268: 293-311. 
Lubova, K.A., Zayats, P.P., Ruban, D.A. \& Tiess, G. (2013). Megaclasts in geoconservation: sedimentological questions, anthropogenic influence, and geotourism potential. Geologos, 19: 321-335.

Migon, P. (2009). Geomorphosites and the World Heritage List of UNESCO. In: Reynard, E., Coratza, P. \& Regolini-Bissig, G. (Eds.). Geomorphosites. F. Pfeil, München, pp. 119-130.

Neche囚, I.-M. \& Erdeli, G. (2014). Geolandscapes and Geotourism: Intergrating Nature and Culture in the Bucegi Mountains of Romania. Landscape Research, doi: 10.1080/01426397.2014.939616.

Panizza, M. \& Piacente, S. (2009). Cultural geomorphology and geodiversity. In: Reynard, E., Coratza, P. \& Regolini-Bissig, G. (Eds.). Geomorphosites. F. Pfeil, München, pp. 35-48.

Poria, Y., Reichel, A. \& Cohen, R. (2013). Tourists perceptions of World Heritage Site and its designation. Tourism Management, 35: 272-274.

Prosser, C.D. (2013). Our rich and varied geoconservation portfolio: the foundation for the future. Proceedings of the Geologists' Association, 124: 568-580.

Rana, R.S. \& Vishwakarma, L.L. (1990). Occurrence of artesian conditions in the Sina river basin of drought prone Karjat Taluka, Ahmednagar district in Maharashtra. In: Proceedings of the all Indian seminar on modern techniques of rainwater harvesting, water conservation and artificial recharge for drinking water, afforestation, horticulture and agriculture. Groundwater Survey and Development Agency (GSDA), Pune, pp. 207-213.

Ruban, D.A. (2010). Quantification of geodiversity and its loss. Proceedings of the Geologists' Association, 121: 326-333.
Ruban, D.A. (2013). Geokonservatsionnyj aspekt nedropol'zovanija: ob'ekty geologitcheskogo nasledija i vzaimosvjaz' ikh tipov [Geoconservation aspect of the interiors exploitation: geological heritage objects and combination of their types]. Nedropol'zovanie XXI vek, 2: 108-113. (in Russian)

Ruban, D.A. \& Kuo, I. (2010). Essentials of geological heritage site (geosite) management: a conceptual assessment of interests and conflicts. Natura Nascosta, 41: 16-31.

Su, Y.-W. \& Lin, H.-L. (2014). Analysis of international tourist arrivals worldwide: The role of world heritage sites. Tourism Management, 40: 46-58.

Tang, C.M. (2000). Ugly Fossil Syndrome. Palaios, 15: 175-176.

Vajda, V. \& Bercovici, A. (2014). The global vegetation pattern across the Cretaceous-Paleogene mass extinction interval: A template for other extinction events. Global and Planetary Change, 122: 29-49.

Walker, G.P.L. (1971). Compound and simple lava flows and flood basalts. Bulletin of Volcanology, 35: 579-590.

Wignall, P.B. (2001). Large igneous provinces and mass extinctions. Earth-Science Reviews, 53: 1-33.

Wilkinson, B.H. (2005). Humans as geologic agents: A deep-time perspective. Geology, 33: 161-164.

Wimbledon, W.A.P. \& Smith-Meyer, S. (Eds.) (2012). Geoheritage in Europe and its conservation. ProGEO, Oslo, 405 pp.

Yang, C.-H., Lin, H.-L. \& Han, C.-C. (2010). Analysis of international tourist arrivals in China: The role of World Heritage Sites. Tourism Management, 31: 827-837. 